\title{
Notification System of Procedures on Standards towards EU and WTO Organization
}

\author{
Dr. Genci Sharko1 \\ Dr. Anni Dasho Sharko² \\ Msc. Georgi Gabrovski ${ }^{3}$ \\ ${ }^{1}$ Polytechnic University of Tirana, Electrical Engineering Faculty, Tirana, Albania \\ ${ }^{2}$ European University of Tirana, Economic and Information Technology Faculty, Tirana, Albania \\ 3Otto.Ltd Sofia, Bulgaria
}

Doi:10.5901/ajis.2015.v4n3p311

\section{Abstract}

The Institute for Standardisation is the national organisation for standardisation established as an autonomous institution of governmental administration for affairs related to the standardisation area. Basic activities of Standardisation Institutes are related to the Law on Standardisation of the countries belonging to, where the scope of jurisdiction is clearly stated in the Law on establishment the Institute for Standardisation of the specific country especially at Balkan region area. Enquiry and Notification Point/Enquiry and Notification System provide notifications on standards and information on situation regarding technical regulations and standards to European CEN, CENELEC and WTO Organization. It improve the transparency and access to information on preparation of standards at national, European and international levels as well as to improve the information system for standardisation to be compatible with International and European Organisations for Standardisation.

Keywords: Institute for Standardisation, Enquiry and Notification Point, Enquiry and Notification System, regulations, standardisation area.CEN, CENELEC, WTO

\section{Introduction}

The activities of a specific Institute for Standardisation in the field of standardisation are stipulated by the Law they develop and approve standardization activities, in conformity with the standardization European Organizations rules.

In order to improve the transparency and access to information on preparation of standards at national, European and international levels as well as to improve the information system for standardization to be compatible with International and European Organizations for Standardization, National Standardization Bodies (NBS) need to use stateof-the-art Information and Communication Technology (ICT).

All the activities of NSB can be performed in an electronic way. The Enquiry and Notification Point System application allow to record and exchange automatically and in electronic way all activates from the National Standardization Body toward the European organization.

(http://www.en.aenor.es/aenor/inicio/home/home.asp), (www.ibf.be/),(www.bas.gov.bal,(www.dps.gov.al).

\section{Business Objectives of the Project}

The objective of the project is to develop the quality infrastructure system and to create an environment for industries within a country to improve their trade relations with the European Union and foreign markets. Transparency and access to information on preparation of standards at national level is very important for national standardization bodies. Compliance with standardisation rules of International and European Organizations is very important also.

Advancement notification procedures on standards towards EU and WTO implemented by Standardization Institute of the Country where it function.

Definition of system for internal consultation and information between Standardization Institutes Enquiry Point and Contact Points of other institutions in the country. Setup an Enquiry and Notification Point/Enquiry and Notification System in place and fully operational, providing notifications on standards and information on situation regarding technical regulations and standards.

The policy of the Standardization Institutes is connected with the information system for extending /upgrading and 
improving standardisation activities on the basis of the European principles.

In view of this policies a conceivable effort shall be made in all operations in order to improve the performance, using new ways of working more intelligently by using state-of-the-art Information and Communication Technology (ICT).

The establishment of fully operational information system will improve the quality of services provided to the customers and will ensure the successful participation of the Standardization Institutes in the work of the International and European standardisation organisations.

Compliance with the good standardisation practice in EU is a necessity. The proper use and implementation of CEN/CENELEC information (exchanged files) requires establishment of relative database with appropriate defined access rights and traceability. (http://www.ibf.be/), (http://www.bas.gov.ba/).

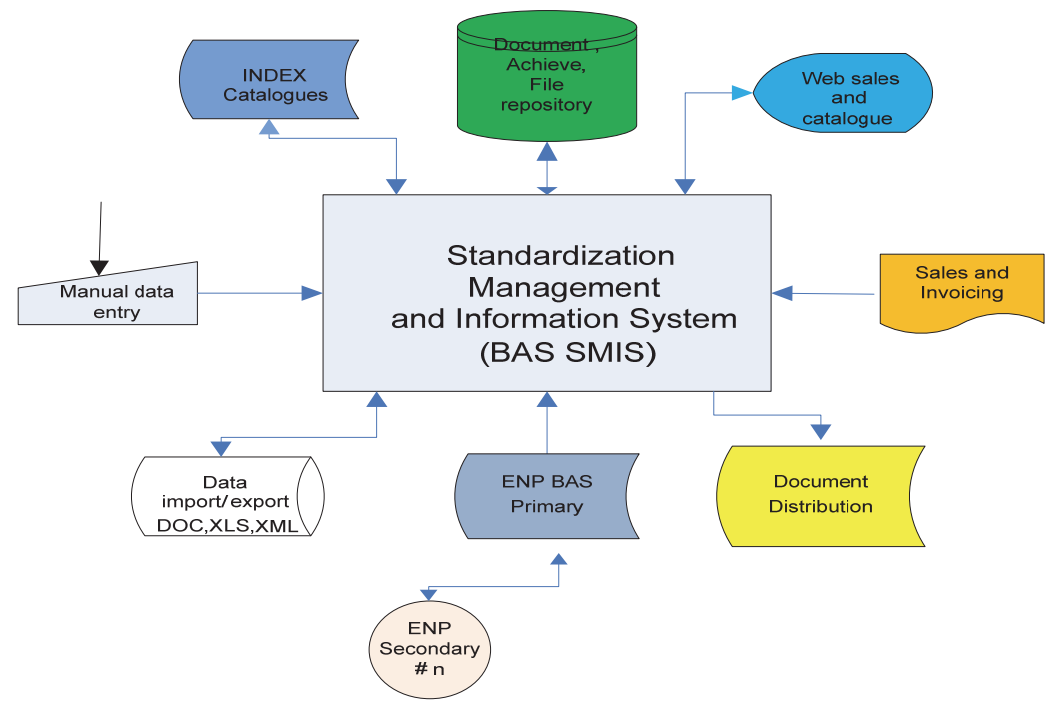

Figure 1: The new modules of the SMIS system.

\section{Activities for Enquiry and Notification Point (ENP) Management System Development}

In order to have Enquiry and Notification Point (ENP) management system the following activities there should be performed:

- Developing information system for enquiry and notification on standards, technical regulation, conformity assessment procedures and work plane towards EU, WTO ISO and IEC implemented by Institute of Standardization.

- Developing of information system with related hardware and software for internal information exchange between Country Enquiry Point and Contact Points of other institutions in Institute of Standardization.

- Setting up the Enquiry and Notification Point/Enquiry communication network and Notification System in place and fully operational, providing notifications on standards and information on situation regarding technical regulations and standards.

- Development of the bibliographical database and a full text database application on the basis of a ENP procedures.

Functional and tested ENP data management system and respective infrastructure needed in order to: provide information service for enquiry and notification on standards and information on situation regarding technical regulations, conformity assessment towards EU/ WTO/ ISO/ IEC by Institute of Standardization; provide information service for internal information exchange between Enquiry Point and Contact Points of other institutions in Institute of Standardization. 


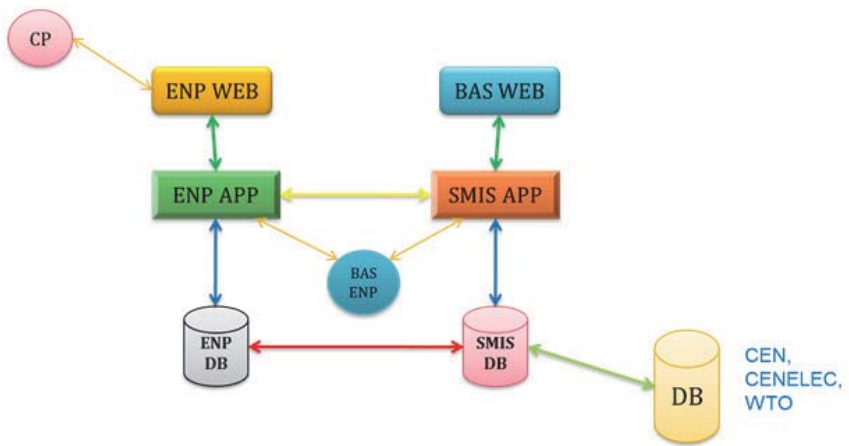

Figure 2: The ENP System Components

\section{Business Function and Performance Requirements}

For all NBS is required to establish National Enquiry Points in accordance with the provisions of the Agreement on Technical Barriers to Trade (TBT) (www.wto.org). The enquiry and notification needs to be linked and stored in one information system where the Institute of Standardization will host and storage the ENP system information. The document flows from the center towards to the Contact Points Units established in government level, some ministries in entity level and cantons level, etc.

Inside the Contact Point Unit one contact person is appointed in order to enable direct coordinator with ENP.

In general it is expected to have in the system 15 ENP units in government level and in some entity level. The ENP in the ministries or other institutes are equipped with standard hardware workstation, scanner, printer etc. The ENP has responsibilities and activities to respond on: Completion of the national obligations of the ENP as reference point for WTO organization. (http://www.ibf.be/), (http://www.bas.gov.ba/), (www.bds-bg.org/en).

\begin{tabular}{|c|c|c|c|c|c|}
\hline Search & Type & Name & Description & File & Date \\
\hline Clear & \multicolumn{5}{|c|}{ Sorted By: date (sql) descending, Type ascending } \\
\hline 锤垔 & CEN & Notification - Jan 2013 & Notifications registered at CCMC & Wiew file & $2013-01-01$ \\
\hline 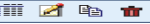 & CENELEC & Notification - Jan 2013 & Notifications registered at CCMC & View file & $2013-01-01$ \\
\hline 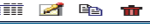 & CEN & Notification - Dec 2012 & Notifications registered at CCMC & View file & $2012-12-01$ \\
\hline$\because$ ID & 1 & & & & \\
\hline - Type * & Tas & k & & & \\
\hline - Status * & Op & - & & & \\
\hline 口 Priority & Min & or $[-$ & & & \\
\hline - Deadline & 201 & 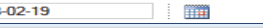 & & & \\
\hline 口 Name * & Con & truction Praduct Directive & & & \\
\hline - Description & & 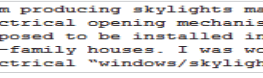 & 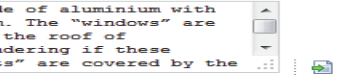 & & \\
\hline
\end{tabular}

Figure 3: Enquiry properties from ENP system perspective

Functional Requirements of the ENP System where the new ENP requirements and the new ENP system have the ability to:

- Connect all ENP, through the WEB interface necessary to control information exchange between parts.

- Record all types of enquiries and documents related to those.

- Store inquiry performed by other ministries. One copy might be inserted in the ENP data base though the contact person in the ENP units.

- Implement and record time scheduling tasks for the enquiry and notification.

The ENP main functionalities and managements, where ENP is responsible for information and notification toward following organizations:

- Provision of information and notification under the TBT agreement and Code of good practice.(www.wto.org)

- Provision of information and notification under the 98/34 EC directive

- Provision of information about notification of working program (WP) to the Information Centre ISO / IEC in 


\section{Geneva}

- Providing notifications to the CEN / CENELEC EN organizations, Guide 12.

ENP is responsible for Notification drafts of:

- purely national standards;

- nonequivalent transposition of international or European standards;

- national annexes to international or European standards;

- amendment of national standards. (http://www.ibf.be/), (http://wwww.bas.gov.ba/), (Ping.W, Yiyi.W, \& Hill.J, 2010), (Ping.W, 2011), (www.wto.org)

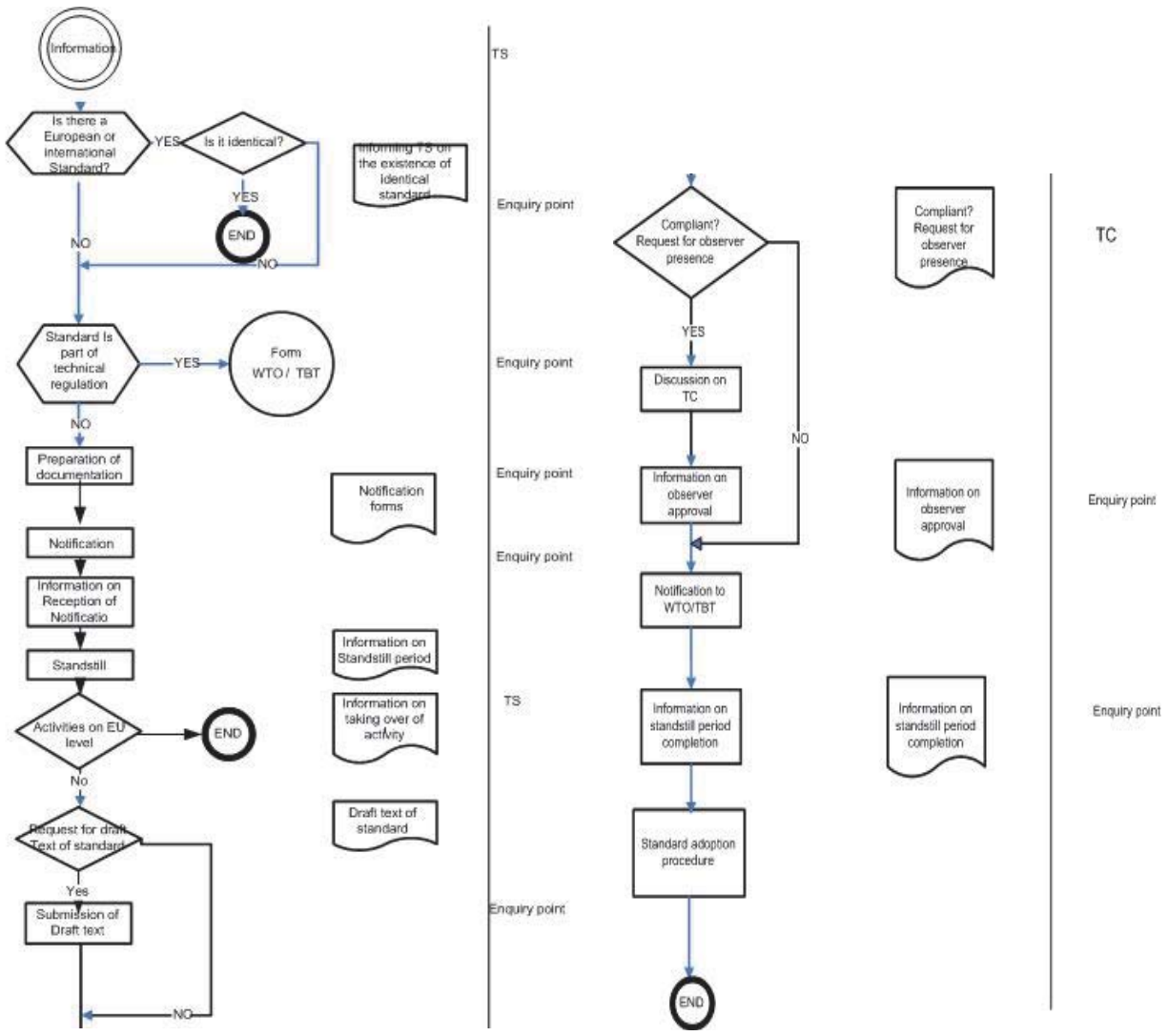

Figure 3: ENP Notification flow diagram

\section{Conclusions}

Every Standardization Institute Technical Committee should inform the ENP via central management when the development of a new standard at national level or the revision of an existing national one is included in the TC working program except for the cases of the implementation of identical or equivalent European or international standard.

Standardization Institute shall notify the National Standardization Program via its National Enquiry Point by sending Form $\mathrm{C}$ to the ISO/IEC Information Center in Geneva no later than the date of its publication on the official Website about the availability of the standardization program.

The National Enquiry Point shall provide the latest version of the working program of Standardization Institute to every WTO member state that has expressed its interest towards the National Enquiry Point to receive it.

The National Enquiry Point ENP shall provide in web site publication of WP for public domain 
- The National Enquiry Point ENP shall provide in web site publication for contact points

- The National Standardization Work Program shall be published at least on the Website or in the Journal in 6 months intervals.

- Standardization Institute working Plane need to be generated with related standard in the field of CEN and CLC implementation.

- WP should be generated for each Standardization Institute committee dealing with WP in order to facilitate work preparation and information for BAS TC secretary.

- Standardization Institute WP document should be distributed to the TC via Standardization Institute document distribution system.

\section{References}

http://www.en.aenor.es/aenor/inicio/home/home.asp

http://www.ibf.be/

http://www.bas.gov.bal

http://www.bds-bg.org/en

http://www.dps.gov.al

https://www.wto.org/

Ping.W, Yiyi.W, \& Hill.J, (January 2010). Standardization Strategy of China-Achievements and Challenges. Economics Series, No. 107, East-West Center Working Paper.

Ping.W, (April 2011). A Brief History of Standards and Standardization Organizations: A Chinese Perspective. Economics Series, No. 117, East-West Center Working Paper.

Kober, N., \& Rentner, D. S. (2011). States' Progress and Challenges in Implementing Common Core State Standards. Center on Education Policy. Washington DC. (Online) available http://www.cep-dc.org/publications/index.cfm?selectedYear=2011

WTO ENPs list (online) available at: http://www.wto.org/english/tratop_e/TBT_e/tbt_enquiry_points_e.htm

EU ENPs list (online) available at: http://ec.europa.eu/enterprise/tbt/index.cfm? fuseaction=Links.viewContact\&dspLang=EN 